\author{
KATARZYNA WESOŁOWSKA \\ Okręgowa Izba Radców Prawnych w Toruniu \\ wesolowskakasia1@gmail.com
}

\title{
Czas pracy pracowników inżynieryjno-technicznych państwowej służby hydrologiczno-meteorologicznej
}

\author{
Working hours of engineering and technical employees of the state hydrological and \\ meteorological service
}

\begin{abstract}
Streszczenie. Problematyka czasu pracy pracowników - co do zasady - uregulowana została w treści ustawy z dnia 26 czerwca 1974 r. - Kodeks pracy. Ustawa ta dopuszcza jednak możliwość regulowania poszczególnych elementów stosunku pracy w innych niż Kodeks pracy przepisach prawnych stanowiących względem niego przepisy szczególne. Również kwestie związane z czasem pracy pracowników mogą być również odmiennie od przepisów Kodeksu pracy regulowane w przepisach szczególnych. Przykładem takiej regulacji jest art. 384 ustawy z dnia 20 lipca 2017 r. Prawo wodne ${ }^{1}$ zawierający unormowania dotyczące rozkładu czasu pracy pracowników inżynieryjnotechnicznych państwowej służby hydrologiczno-meteorologicznej.

Celem niniejszego opracowania jest analiza powołanej regulacji szczególnej. Przedstawione zostaną różnice pomiędzy regulacjami zawartymi w Kodeksie pracy i w Prawie wodnym. Uwypuklone zostaną istotne problemy interpretacyjne, które budzą ww. rozwiązania legislacyjne. Sformułowane zostaną również uwagi de lege ferenda.
\end{abstract}

Słowa kluczowe: czas pracy; prawo wodne; państwowa służba hydrologiczno-meteorologiczna.

Summary. The issue of employees' working hours - in principle - is regulated in the content of the Act of 26 June 1974 - Labor Code. However, this Act allows the possibility of regulating individual elements of the employment relationship in acts other than the Labor Code which constitute special regulations for it. Also, issues related to employees' working hours may be differently regulated in specific regulations other than the regulations of the Labor Code. An example of such a regulation is art. 384 of the Act of 20 July 2017 Water Law containing regulations regarding the distribution of working hours of engineering and technical employees of the state hydrological and meteorological service.

The purpose of this study is to analyze the specific regulation. Differences between the regulations contained in the Labor Code and the Water Law will be presented. Significant interpretation problems that arise from the abovementioned legislative solutions will be highlighted. De lege ferenda comments will also be made.

Key words: working time; water law; the state hydrological and meteorological service.

\footnotetext{
${ }^{1}$ Dz. U. z 2020 r. poz. 310, w dalszej części określana również jako P.w.
} 


\section{Wstęp}

Problematyka czasu pracy pracowników - co do zasady - uregulowana została w treści ustawy z dnia 26 czerwca 1974 r. - Kodeks pracy ${ }^{2}$. Ustawa ta w art. $128 \S 1$ K.p. definiuje czas pracy jako czas, w którym pracownik pozostaje w dyspozycji pracodawcy w zakładzie pracy lub w innym miejscu wyznaczonym do wykonywania pracy $w$ przepisach kolejnych, regulując w sposób kompleksowy organizację czasu pracy pracowników.

Zauważyć należy, że Kodeks pracy dopuszcza możliwość regulowania poszczególnych elementów stosunku pracy w innych niż Kodeks pracy przepisach prawnych stanowiących względem niego przepisy szczególne. Przepis art. 5 K.p. stanowi, że ,jeżeli stosunek pracy określonej kategorii pracowników regulują przepisy szczególne, przepisy kodeksu stosuje się W zakresie nieuregulowanym tymi przepisami”. W związku z powyższym, w myśl zasady lex specialis derogat legi generali, do określonej grupy pracowników zastosowanie mogą mieć wyłącznie przepisy szczególne. Podkreślić jednak należy, że w zakresie, który pozostanie nieuregulowany przepisami szczególnymi zastosowanie znajdują przepisy Kodeksu pracy. Kwestie związane z czasem pracy pracowników mogą być również odmiennie od przepisów Kodeksu pracy regulowane w przepisach szczególnych. Przykładem takiej regulacji jest art. 384 ustawy z dnia 20 lipca 2017 r. Prawo wodne $^{3}$ zawierający unormowania dotyczące rozkładu czasu pracy pracowników inżynieryjno-technicznych państwowej służby hydrologiczno-meteorologicznej.

Celem niniejszego opracowania jest analiza powołanej regulacji szczególnej. Przedstawione zostaną różnice pomiędzy regulacjami zawartymi w Kodeksie pracy i w Prawie wodnym. Uwypuklone zostaną istotne problemy interpretacyjne, które budzą ww. rozwiązania legislacyjne. Sformułowane zostaną również uwagi de lege ferenda.

\section{Rozkład czasu pracy}

Z literalnego brzmienia art. 384 Prawa wodnego wynika, że przepis ten reguluje kwestię rozkładu czasu pracy określonej grupy pracowników, tj. pracowników inżynieryjnotechnicznych państwowej służby hydrologiczno-meteorologicznej. Przepis art. 384 ust. 1 P.w. stanowi, że „wobec pracowników inżynieryjno-technicznych zatrudnionych w ramach państwowej służby hydrologiczno-meteorologicznej wprowadza się rozkład czasu pracy: 1) zmianowy - na stanowiskach, na których jest to konieczne ze względu na szczególne warunki pracy lub warunki atmosferyczne; 2) podstawowy - na pozostałych stanowiskach".

\footnotetext{
${ }^{2}$ Tj. Dz. U. z 2019 r. poz. 1040 ze zm., w dalszej części określana również jako K.p.

${ }^{3}$ Dz. U. z 2020 r. poz. 310, w dalszej części określana również jako P.w.
} 
W ust. 3 i 4 art. 384 P.w. doprecyzowano na czym ma polegać zmianowy i podstawowy rozkład czasu pracy. Z kolei art. 384 ust. P.w. wskazuje na podmiot uprawniony do określania stanowisk, na których obowiązuje zmianowy i podstawowy rozkład czasu pracy. Jest nim dyrektor Instytutu Meteorologii i Gospodarki Wodnej - Państwowego Instytutu Badawczego. W pierwszej kolejności zauważyć należy, że pojęcie „rozkładu czasu pracy” stanowi pojęcie języka prawnego i wielokrotnie pojawia się w treści Kodeksu pracy, lecz nie posiada ono swojej legalnej definicji. Niemniej jednak jego znaczenie można odtworzyć na podstawie całokształtu przepisów o czasie pracy ${ }^{4}$.Przedstawiciele doktryny prawa pracy wiążą się omawiane pojęcie z organizacją czasu pracy. Tytułem przykładu wskazać należy, że K. Rączka definiuje to pojęcie jako „sposób zagospodarowania czasu pracy wynikający $\mathrm{z}$ danego systemu czasu pracy $\mathrm{z}$ uwzględnieniem dopuszczonych $\mathrm{w}$ jego ramach maksymalnych norm czasu pracy, okresów rozliczeniowych oraz przerw w pracy" ${ }^{5}$ zaś M.B. Rycak ujmuje pojęcie rozkładu czasu pracy jako „sposób rozplanowania czasu pracy, w którym pracownik jest zobowiązany pozostawać w dyspozycji pracodawcy w poszczególnych dniach i tygodniach okresu rozliczeniowego ${ }^{6 \%}$. Zdaniem Ł. Pisarczyka rozkładem czasu pracy jest ,sposób rozplanowania czasu, w którym pracownik jest zobowiązany pozostawać $\mathrm{W}$ dyspozycji pracodawcy $\mathrm{w}$ poszczególnych dniach i tygodniach okresu rozliczeniowego, z uwzględnieniem ograniczeń właściwych dla organizacji czasu pracy, w ramach której pracownik jest zatrudniony ${ }^{7}$ ". Z kolei L. Florek i T. Zieliński wskazują na dwa znaczenia pojęcia „rozkładu czasu pracy”. W ich ocenie pojęcie to oznacza „rozłożenie danego wymiaru czasu pracy w poszczególnych dniach i tygodniach pracy, co obejmuje także dni wolne od pracy ${ }^{8}$, , a ponadto „dobowy rozkład czasu pracy i obejmuje określenie początku i końca pracy, przerw w pracy, przesuwania zmian przy pracy zmianowej","

Rozkład czasu pracy może mieć charakter zbiorowy, gdy obejmuje wszystkich pracowników zatrudnionych u danego pracodawcy lub co najmniej grupę pracowników wyodrębnioną według kryterium rodzaju czy miejsca pracy lub indywidualny, gdy odnosi się do konkretnych pracowników ${ }^{10}$.

\footnotetext{
${ }^{4}$ Ł. Pisarczyk, Ksztaltowanie rozkladu czasu pracy [w:] Czas pracy, pod red. L. Florka, Warszawa 2011, s. 184.

${ }^{5} \mathrm{~K}$. Rączka, Ustalanie systemów i rozkladów czasu pracy na gruncie kodeksu pracy, PiZS 2004, Nr 2, s. 30

${ }^{6}$ M. B. Rycak, Wymiar i rozktad czasu pracy, Warszawa 2008, s. 60.

${ }^{7}$ Ł. Pisarczyk [w:]Kodeks pracy. Komentarz pod red. L. Florka, LEX 2017/el.

${ }^{8}$ L. Florek, T. Zieliński, Prawo pracy, Warszawa 2006, s. 162.

9 Ibidem

${ }^{10}$ Ł. Pisarczyk [w:]Prawo, LEX/el.
} 
Porównując treść art. 384 P.w. z przeprowadzoną analizą pojęcia rozkładu czasu pracy obowiązującą w prawie pracy, zauważyć można, że w Prawie wodnym wprowadzono pojęcie rozkładu czasu pracy, nadając mu inny zakres znaczeniowy niż w Kodeksie pracy. W mojej ocenie art. 384 P.w. odnosi się do systemów a nie rozkładu czasu pracy. Tym samym w jego treści doszło do niewłaściwego użycia pojęcia „rozkładu czasu pracy”11.

\section{III.System czasu pracy}

Podobnie jak pojęcie „rozkładu czasu pracy” również pojęcie „systemu czasu pracy” nie posiada definicji legalnej, mimo że wielokrotnie pojawia się w treści Kodeksu pracy. Pojęcie to zostało jednak zdefiniowane w literaturze przedmiotu prawa pracy. A. Sobczyk wskazuje, że ,przez system czasu pracy należy rozumieć typ dopuszczalnej przez prawo organizacji czasu pracy w przypadku wystąpienia określonych przez przepisy przesłanek. Na system składa się określona kombinacja (w niektórych przypadkach kilka kombinacji) maksymalnego dobowego wymiaru czasu pracy oraz okresu rozliczeniowego"12. K. Rączka formułuje bardziej rozbudowaną definicję, zgodnie z którą system czasu pracy stanowi „konstrukcję prawną wyznaczającą nominał i sposób organizacji czasu pracy. Elementami tej konstrukcji są przede wszystkim sposób określenia czasu pracy oraz normy czasu pracy - dobowa, przeciętna tygodniowa. Elementami uzupełniającymi są natomiast okresy rozliczeniowe, dopuszczalność stosowania przerwy niewliczanej do czasu pracy oraz z góry założona praca W niedziele i święta" ${ }^{\prime 13}$. Na relację pomiędzy systemem czasu pracy a rozkładem czasu pracy wskazał A. Sobczyk, zdaniem którego pojęcie „rozkładu czasu pracy” odnosi się do modelu organizacji czasu pracy w ramach danego systemu czasu pracy ${ }^{14} \cdot \mathrm{Z}$ powyższego wynika, że rozkład czasu pracy ma charakter pochodny w stosunku do systemu czasu pracy ${ }^{15}$. Zgodzić się należy z Ł. Pisarczykiem, że pojęciu systemu czasu pracy należy nadawać znaczenie, w jakim jest ono używane przez ustawodawcę w przepisach działu szóstego Kodeksu pracy ${ }^{16}$.

Odniesienie przeprowadzonych rozważań do treści art. 384 P.w. uzasadnia sformułowaną tezę, że art. 384 P.w. odnosi się do systemu, a nie rozkładu czasu pracy. Wbrew literalnemu brzmieniu art. 384 P.w. zarówno w przepisach Kodeksu pracy jak i w nauce prawa pracy nie wyróżnia się podstawowego ani zmianowego rozkładu czasu

${ }^{11} \mathrm{Na}$ inne przykłady błędnego użycia pojęcia „rozkładu czasu pracy” w przepisach ustawowych wskazuje Ł. Prasołek, Rozkład, indywidualny rozkład i haromonogram czasu pracy oraz ich wzajemne korelacje [w:] Czas pracy, pod red. L. Florka, Warszawa 2011, s. 186-187.

${ }_{12}^{12}$ A. Sobczyk, Zasady prawnej regulacji czasu pracy, Warszawa 2005, s. 158.

${ }^{13} \mathrm{~K}$. Rączka, Ustalanie, s. 15.

${ }^{14}$ A. Sobczyk, Zasady, s. 159.

${ }^{15}$ Ł. Pisarczyk, Ksztaltowanie, s. 121.

${ }^{16}$ Ł. Pisarczyk [w:] Prawo, LEX/el. 
pracy. Kodeks pracy wyróżnia jednak, mimoże wprost go tak nie nazywa, podstawowy system czasu pracy, który uregulowany został w art. 129 § 1 K.p. Zgodnie natomiast z art. 146 K.p. „Praca zmianowa jest dopuszczalna bez względu na stosowany system czasu pracy".

Powyższe rozważania skłaniają do przedstawienia postulatu de lege ferenda, aby terminologia zastosowana w art. 384 P.w. została ujednolicona z przepisami Kodeksu pracy.

Niemniej jednak w treści niniejszego opracowania, odnosząc się do regulacji zawartych w Prawie wodnym, stosować będę pojęcia nim objęte, czyli zmianowego i podstawowego rozkładu czasu pracy.

\section{IV.Zmianowy rozkład czasu pracy}

Analiza art. 384 P.w. pozwala postawić tezę, iż zmianowy rozkład czasu pracy, o którym mowa w tym przepisie, stanowi w istocie odmianę równoważnego systemu czasu pracy.

W pierwszej kolejności wskazać należy na regulację Kodeksu pracy, zgodnie z którą równoważny system czasu pracy może być stosowany, jeżeli jest to uzasadnione rodzajem pracy lub jej organizacją na zasadach określonych w treści art. 135 K.p. (przepis ten uwzględnia również szczególnie uzasadnione przypadki oraz prace uzależnione od pory roku lub warunków atmosferycznych), przy pracach polegających na dozorze urządzeń lub związanych z częściowym pozostawaniem w pogotowiu do pracy na zasadach określonych w treści art. 136 K.p. oraz do pracowników zatrudnionych przy pilnowaniu mienia lub ochronie osób, a także pracowników zakładowych straży pożarnych i zakładowych służb ratowniczych na zasadach określonych w treści art. 137 K.p.

Uzasadnieniem postawionej na wstępie tezy jest fakt, że $w$ treści art. 384 ust. 1 pkt 1 P.w. wskazano, że zmianowy rozkład czasu pracy może być stosowany na stanowiskach, na których jest to konieczne ze względu na szczególne warunki pracy lub warunki atmosferyczne. Art. 384 P.w. w treści ust. 3, podobnie jak ma to miejsce w przypadku regulacji Kodeksu pracy odnoszących się do równoważnego systemu czasu pracy, określa maksymalny czas, w jakim zadania mogą być wykonywane, jednak czyni to W sposób szczególny. Zgodnie z powołanym przepisem zmianowy rozkład czasu pracy pracowników polega na wykonywaniu powierzonych im zadań nie dłużej niż przez 48 godzin, po których następuje co najmniej 48 godzin wolnych od pracy.

Z powyższych rozważań wynika, że dobowy wymiar czasu pracy został wydłużony ponad 8 godzin. Należy zwrócić uwagę również na to, że Kodeks pracy w art. 133. wprowadza ograniczenie w organizacji czasu pracy polegające na obowiązku zapewnienia 
pracownikowi nieprzerwanego odpoczynku tygodniowego, który nie może być krótszy niż minimalny okres wskazany $\mathrm{w}$ treści powołanego przepisu. W swojej treści art. 384 P.w. nie odsyła do tego przepisu. Dla porównania zauważyć należy, że art. 136 K.p. regulujący możliwość stosowania systemu równoważnego czasu pracy przy pracach polegających na dozorze urządzeń lub związanych z częściowym pozostawaniem w pogotowiu do pracy wskazuje, że „pracownikowi przysługuje, bezpośrednio po każdym okresie wykonywania pracy w przedłużonym dobowym wymiarze czasu pracy, odpoczynek przez czas odpowiadający co najmniej liczbie przepracowanych godzin, niezależnie od odpoczynku przewidzianego w art. 133”. Brak odesłania w Prawie wodnym do art. 133 K.p. nie oznacza, że pracownikom inżynieryjno-technicznym zatrudnionym w ramach państwowej służby hydrologiczno-meteorologicznej w zmianowym rozkładzie czasu pracy nie przysługuje prawo do odpoczynku na podstawie powołanego przepisu. W mojej ocenie prawo to przysługuje niezależnie od godzin wolnych od pracy wskazanych w treści art. 384 ust. 3 P.w.

\section{Podstawowy rozklad czasu pracy}

Zgodnie z art. 384 ust. 4 P.w. podstawowy rozkład czasu pracy polega na wykonywaniu powierzonych pracownikom zadań $\mathrm{w}$ dobowym wymiarze czasu pracy nieprzekraczającym 8 godzin w okresie rozliczeniowym nieprzekraczającym 3 miesięcy. Powołany przepis stanowi odstępstwo od regulacji Kodeksu pracy odnoszącej się do podstawowego systemu czasu pracy, zgodnie z którym „czas pracy nie może przekraczać 8 godzin na dobę i przeciętnie 40 godzin w przeciętnie pięciodniowym tygodniu pracy w przyjętym okresie rozliczeniowym nieprzekraczającym 4 miesięcy, z zastrzeżeniem art. 135-138, 143 i 144”. Z powyższego wynika, że Kodeks pracy różnicuje długość okresu rozliczeniowego od konkretnego systemu czasu pracy. Zgodnie z powołanym przepisem Prawa wodnego został on skrócony do 3 miesięcy.

\section{VI.Okres rozliczeniowy}

Kolejnym pojęciem, które nie ma swojej legalnej definicji, mimo że ustawodawca posłużył się nim wielokrotnie w treści przepisów Kodeksu pracy jest pojęcie okresu rozliczeniowego. W literaturze przedmiotu definiuje się okres rozliczeniowy jako „okres czasu mierzony w jednostkach kalendarzowych, w ramach którego pracodawca powinien rozliczyć czas pracy pracownika zarówno co do godzin, jak i dni ${ }^{17 \%}$. Rozliczenie powinno polegać na

\footnotetext{
${ }^{17}$ A. Sobczyk, Zasady, s. 160.
} 
zbilansowaniu wartości przeciętnych, w tym zwłaszcza przeciętnej tygodniowej normy czasu pracy w przeciętnie pięciodniowym tygodniu pracy ${ }^{18 \%}$.

Odnosząc się do okresów rozliczeniowych czasu pracy pracowników inżynieryjnotechnicznych zatrudnionych w ramach państwowej służby hydrologiczno-meteorologicznej, zauważyć należy, że w ust. 5 art. 384 P.w. wskazano, że czas pracy pracowników, o których mowa w ust. 1 (zatrudnionych w zmianowym i podstawowym rozkładzie czasu pracy) nie może przekraczać przeciętnie 40 godzin tygodniowo $\mathrm{W}$ okresie rozliczeniowym nieprzekraczającym 6 miesięcy, co stanowi odstępstwo od regulacji zawartych $\mathrm{w}$ treści Kodeksu pracy. Z uwagi na to, że w treści Prawa wodnego nie zawarto jakichkolwiek innych regulacji odnoszących się do okresu rozliczeniowego pracowników zatrudnionych w zmianowym rozkładzie czasu pracy, uznać należy, że art. 384 P.w. w omawianej części niewątpliwie odnosi się do tej grupy pracowników inżynieryjno-technicznych państwowej służby hydrologiczno-meteorologicznej.

W mojej ocenie art. 384 P.w. jest wewnętrznie sprzeczny w części odnoszącej się do okresu rozliczeniowego pracowników zatrudnionych w podstawowym rozkładzie czasu pracy. Jak wcześniej wskazano, okres rozliczeniowy w podstawowym rozkładzie czasu pracy nie może przekroczyć 3 miesięcy, zaś art. 384 ust. 5 P.w. nie zawiera jakiegokolwiek wyłączenia dotyczącego pracowników zatrudnionych w powołanym rozkładzie czasu pracy. Oznacza to, że zarówno okres rozliczeniowy wynoszący 3 miesiące (wynikający z ust. 4), jak i okres rozliczeniowy wynoszący 6 miesięcy (wynikający z ust. 5) mają zastosowanie do pracowników inżynieryjno-technicznych państwowej służby hydrologiczno-meteorologicznej zatrudnionych w podstawowym rozkładzie czasu pracy. W mojej ocenie taki dualizm jest niedopuszczalny.

Zdaniem M. Kałużnego, okres rozliczeniowy powołany w treści art. 384 ust. 5 P.w. należy odnosić wyłącznie do zmianowego systemu czasu pracy, nie wskazując jakiegokolwiek uzasadnienia dla takiego twierdzenia ${ }^{19}$. Skoro jednak powołany przepis wyraźnie odsyła do ust. 1, czyli wskazuje zarówno pracowników zatrudnionych w zmianowym jak i podstawowym rozkładzie czasu pracy, należy przyjąć, że ma on zastosowanie do obu grup pracowników inżynieryjno-technicznych państwowej służby hydrologiczno-meteorologicznej. De lege ferenda kwestia ta powinna zostać uregulowana w sposób niebudzący wątpliwości.

\footnotetext{
${ }^{18}$ Ł. Pisarczyk [w:] Prawo, LEX/el.

${ }^{19}$ M. Kałużny, Prawo wodne. Komentarz, LEX 2016/el.Art. 384 P.w. stanowi dosłowne powtórzenie regulacji zawartej w treści art. 108a uchylonej ustawy z dnia 18 lipca 2001 r. Prawo wodne (Dz. U. z 2001 r., Nr 115, poz. 1229 ze zm.)
} 


\section{Zasada przeciętnie pięciodniowego tygodnia pracy}

Przepis art. 129 § 1 K.p. stanowi, że czas pracy nie może przekraczać 8 godzin na dobę i przeciętnie 40 godzin w przeciętnie pięciodniowym tygodniu pracy w przyjętym okresie rozliczeniowym nieprzekraczającym 4 miesięcy. Poza tym, że powołany przepis określa kształt tzw. podstawowego czasu pracy,on wyznacza on również normy czasu pracy, określa przeciętną tygodniową liczbę dni pracy (pośrednio również liczbę dni wolnych) oraz długość okresu rozliczeniowego, która podlega modyfikacji w zależności od systemu pracy ${ }^{20}$.

Odnosząc się w pierwszej kolejności do normy czasu pracy, należy stwierdzić, że pojęcie to również nie posiada legalnej definicji. W literaturze przedmiotu określana jest jako „przyjęta granica, maksimum czasu pozostawania pracownika do dyspozycji pracodawcy w obrębie doby pracowniczej i tygodnia pracy ${ }^{21 "}$.Z zasady przeciętnie pięciodniowego tygodnia pracy wynika zaś, że w okresie rozliczeniowym powinien on obejmować maksymalnie 5 dni pracy oraz co najmniej 2 dni wolne ${ }^{22}$.

W treści art. 384 ust. 5 P.w. nie odniesiono się w żaden sposób do tego, iludniowy przeciętnie jest tydzień pracy pracowników inżynieryjno-technicznych zatrudnionych w ramach państwowej służby hydrologiczno-meteorologicznej. Pamiętać jednak należy o wyrażonej w treści art. 5 K.p. zasadzie lex specialis derogat legi generali, zgodnie z którą pierwszeństwo mają regulacje szczególne, zaś przepisy Kodeksu pracy stosuje się pomocniczo $^{23}$. Skoro zatem brak jest odpowiedniej regulacji w treści Prawa wodnego uznać należy, że również do pracowników inżynieryjno-technicznych zatrudnionych w ramach państwowej służby hydrologiczno-meteorologicznej zastosowanie ma zasada przeciętnie pięciodniowego tygodnia pracy wyrażona w treści art. 129 § 1 K.p.

\section{Indywidualny rozkład czasu pracy oraz ustalenia systemów, rozkładów czasu pracy oraz okresów rozliczeniowych}

Co do zasady rozkłady czasu pracy ustalane są dla ogółu pracowników w treści układu zbiorowego pracy, regulaminu pracy albo obwieszczenia. Zgodnie z art. 142 K.p. „na pisemny wniosek pracownika pracodawca może ustalić indywidualny rozkład jego czasu pracy w ramach systemu czasu pracy, którym pracownik jest objęty”. Co więcej, również w przypadkach wyraźnie wskazanych przez ustawodawcę można zastosować indywidualny

\footnotetext{
${ }^{20}$ Ł. Pisarczyk [w:] Prawo, LEX/el.

${ }^{21}$ M. B. Rycak, Wymiar, s. 52.

${ }^{22}$ Ł. Pisarczyk [w:] Prawo, LEX/el.

${ }^{23}$ K. Rączka[w:] M. Gersdorf, M. Raczkowski, K. Rączka, Kodeks pracy. Komentarz, LEX/el.
} 
rozkład czasu pracy, w którym możliwe jest określenie innych dni oraz godzin rozpoczynania i kończenia pracy niż w odniesieniu do ogółu pracowników. Powyższe służyć ma uwzględnieniu specyficznych potrzeb konkretnych pracowników ${ }^{24}$.

Przykładem takiej regulacji jest art. 384 ust. 6 P.w., zgodnie z którym „w szczególnie uzasadnionych przypadkach dyrektor Instytutu Meteorologii i Gospodarki Wodnej Państwowego Instytutu Badawczego może ustalić indywidualny rozkład czasu pracy pracowników, o których mowa w ust. 1, w ramach normy czasu pracy, o której mowa w ust. 4".Indywidualny rozkład czasu pracy może zostać zastosowany zarówno do pracowników zatrudnionych w zmianowym, jak i podstawowym rozkładzie czasu pracy.

Art. 142 K.p. stanowi, że indywidualny rozkład czasu pracy może zostać ustalony na indywidualny wniosek pracownika. Prawo wodne nie reguluje, kto powinien wystąpić z inicjatywą zastosowania takiego systemu, stanowiąc jedynie, że podmiotem, który go ustala jest dyrektor Instytutu Meteorologii i Gospodarki Wodnej - Państwowego Instytutu Badawczego. Tym samym uznać należy, że w odróżnieniu do regulacji Kodeksu pracy, na podstawie Prawa wodnego indywidualny rozkład czasu pracy może zostać ustalony zarówno na wniosek pracownika, jak i z inicjatywy samego pracodawcy.

Przechodząc do ustalenia systemów, rozkładów czasu pracy oraz okresów rozliczeniowych zauważyć należy, że zgodnie z ogólną zasadą zawartą w art. 150 § 1 K.p. z zastrzeżeniami wynikającymi z powołanego przepisu systemy i rozkłady czasu pracy oraz przyjęte okresy rozliczeniowe czasu pracy ustala się w układzie zbiorowym pracy lub w regulaminie pracy albo $\mathrm{w}$ obwieszczeniu, jeżeli pracodawca nie jest objęty układem zbiorowym pracy lub nie jest obowiązany do ustalenia regulaminu pracy.W związku z tym, że W treści Prawa wodnego brak jest regulacji szczególnej, która odmiennie regulowałaby powołaną kwestię, uznać należy, że również w przypadku pracowników inżynieryjnotechnicznych zatrudnionych $\mathrm{w}$ ramach państwowej służby hydrologiczno-meteorologicznej zastosowanie ma powołana powyżej ogólna zasada.

\section{Wnioski}

Przepis Prawa wodnego odnoszący się do czasu pracy pracowników inżynieryjnotechnicznych państwowej służby hydrologiczno-meteorologicznej stanowi regulację szczególną względem przepisów Kodeksu pracy. Jak wynika z przeprowadzonych rozważań, regulację tę uznać należy za niedoskonałą. W jej treści zastosowano pojęcia występujące

\footnotetext{
${ }^{24}$ L. Pisarczyk [w:] Prawo, LEX/el.
} 
w treści Kodeksu pracy, nadając im jednak zupełnie inne znaczenie, a co więcej wprowadzono sprzeczne regulacje, które powodować mogą istotne problemy interpretacyjne.

Zauważyć należy, że analizowana regulacja w obecnie obowiązującej treści obowiązywała również w ustawie Prawo wodne z 2001 r. $^{25}$ Pomimo zastąpienia powołanej ustawy nową, treść przepisu regulującego czas pracy pracowników inżynieryjno-technicznych państwowej służby hydrologiczno-meteorologicznej pozostała bez zmian.

De lege ferendaterminologia zastosowana w treści art. 384 P.w. powinna zostać ujednolicona $\mathrm{z}$ przepisami Kodeksu pracy, jak również kwestia długości okresu rozliczeniowego $\mathrm{w}$ poszczególnych systemach pracy powinna zostać uregulowana w sposób niebudzący wątpliwości.

\section{Bibliografia:}

Florek L., Zieliński T., Prawo pracy, Warszawa 2006

Kałużny M., Prawo wodne. Komentarz, LEX 2016/el

Pisarczyk Ł. [w:] Kodeks pracy. Komentarz pod red. L. Florka, LEX 2017/el.

Pisarczyk Ł., Kształtowanie rozkładu czasu pracy [w:] Czas pracy, pod red. L. Florka, Warszawa 2011.

Prasołek Ł., Rozkład, indywidualny rozkład $i$ haromonogram czasu pracy oraz ich wzajemne korelacje [w:] Czas pracy, pod red. L. Florka, Warszawa 2011

Rączka K. [w:] M. Gersdorf, M. Raczkowski, K. Rączka, Kodeks pracy. Komentarz, LEX/el.

Rączka K., Ustalanie systemów i rozkładów czasu pracy na gruncie kodeksu pracy, PiZS 2004, Nr 2

Rycak M.B., Wymiar i rozktad czasu pracy, Warszawa 2008

Sobczyk A., Zasady prawnej regulacji czasu pracy, Warszawa 2005

\footnotetext{
${ }^{25}$ Wprowadzony został ustawą z dnia 5 stycznia 2011 r. o zmianie ustawy - Prawo wodne oraz niektórych innych ustaw (Dz. U. z 2011 r., Nr 32, poz. 159).
} 